\title{
The use of benzodiazepines by women cared for at a Family Health Unit*
}

\author{
O uso de benzodiazepínicos por mulheres atendidas em uma Unidade de Saúde da Família \\ El empleo de benzodiazepinas por mujeres atendidas en una Unidad de Salud de la Familia
}

Paula Adriana da Silva1, Letícia Yamawaka de Almeida ${ }^{1}$, Jacqueline de Souza²

How to cite this article:

Silva PA, Almeida LY, Souza J. The use of benzodiazepines by women cared for at a Family Health Unit. Rev Esc Enferm USP. 2019;53:e03419. DOI: http:// dx.doi.org/10.1590/S1980-220X2017038903419

* Extracted from the dissertation: "O uso de benzodiazepínicos em mulheres atendidas pela Estratégia de Saúde da Família em um município do interior paulista”, Escola de Enfermagem de Ribeirão Preto, Universidade de São Paulo, 2017.

1 Universidade de São Paulo, Escola de Enfermagem de Ribeirão Preto, Ribeirão Preto, SP, Brazil.

${ }^{2}$ Universidade de São Paulo, Escola de Enfermagem de Ribeirão Preto, Departamento de Enfermagem Psiquiátrica e Ciências Humanas, Ribeirão Preto, SP, Brazil.

\begin{abstract}
Objective: Estimate the prevalence of benzodiazepine use by adult women at a Family Health Unit and identify the risk factors associated with this usage. Method: Quantitative cross-sectional study that employed secondary data developed at a Family Health Unit in the state of São Paulo, Brazil. We collected the data from the following sources: medical charts, registration forms, and the archive of prescriptions from the pharmacy at the referred health unit. We employed the chi-squared, Student's t, and Mann-Whitney tests, as well as logistic regression analysis. Results: We identified 81 benzodiazepine users amongst 1,094 adult women (7.4\%). Regarding the risk factors, the comparison between the groups of benzodiazepine users $(n=64)$ and non-users $(n=70)$ showed that having a chronic disease and using other psychotropic drugs were significantly associated with the use of benzodiazepines. Conclusion: The prevalence found was lower than the described in previous studies performed in Primary Health Units. The group that must receive greater attention regarding the consumption of benzodiazepines is that of middle-aged women or older, with low education levels, and chronic illnesses.
\end{abstract}

\section{DESCRIPTORS}

Psychotropic, Drug; Women; Prevalence; Risk Factors; Chronic Disease; Family Health Strategy. 


\section{INTRODUCTION}

Brazil has been pointed out as one of the leading world consumers of benzodiazepines (BZD), and the indiscriminate use of such drugs constitutes a significant public health problem, primarily due to their side effects and the potential to induce tolerance and long-term psychological and/ or physiological dependency ${ }^{(1-4)}$.

Women are more susceptible to receiving BZD prescriptions, and the refilling of the prescription is not always obtained from direct contact between the patient and the physician $^{(4-8)}$. In this sense, some researchers ${ }^{(7,9-10)}$. have been widely discussing the gender bias regarding the use of the psychotropic drug.

Recent studies discussing the use of BZD by women have been performed in countries such as France ${ }^{(5)}$, Norway $^{(9)}, \mathrm{USA}^{(6,11)}$ Canada $^{(7,12)}$, United Kingdom ${ }^{(13)}$, Spain $^{(8,14)}$, and Brazil ${ }^{(1,10,15)}$. Such studies were conducted considering different health services, but few were focused on primary care ${ }^{(6,14,15)}$.

It is worth noting that, although one of the main characteristics of primary care is the work focused on prevention and health promotion, medicalization has been the primary resource employed in mental health care by this department's teams, mainly due to the scarcity of available specialized support ${ }^{(16)}$. From this problem arises the importance of studies about the use of BZD by women in this setting, with emphasis to possible differences between Primary Health Units (PHU) and Family Health Units (FHU). It is our understanding that such studies can support discussions and contribute to a more effective approach of the phenomenon in the work processes of the teams.

We based this study on the following research questions: Is the prevalence of BZD use by women of a given FHU lower than that identified in previous studies carried out in other health services? Are social vulnerability situations such as low income or education levels and having chronic illnesses risk factors for the use of BZD among women cared for at the FHU?

Hence, the objective of this study was to estimate the prevalence of BZD use among adult women of an FHU in the state of São Paulo, Brazil, and identify the risk factors associated with this use, considering as parameter for comparison non-user women from the same unit.

\section{METHOD}

\section{StUdY TYPE}

This is a quantitative cross-sectional study specifically developed at an FHU of a neighborhood located in between the periphery and the central and wealthier areas of a municipality in the state of São Paulo, Brazil.

\section{Population}

The unit has a family health team and cares for 3,048 people (931 families), of which 1,092 were women over 18 years old.

\section{SELECTION CRITERIA}

We developed this study in two phases: the first consisted of the identification of the number of BZD users at the unit. To do so, we consulted all the medical charts of women over 18 years old $(\mathrm{n}=1,092)$, as well as all the medicine dispensing records of the reference pharmacy corresponding to the period from August 2014 to August $2015(\mathrm{n}=176)$. The consultation of the records aimed at obtaining a quality parameter, given the possible biases of the medical chart records.

The second phase of the study consisted of collecting information related to the social and clinical conditions of the BZD users (group 1) and non-users (group 2).

\section{SAMPLE DEFINITION}

In group 1, we included information on all the BZD users identified in the first phase of the study $(n=81)$.

For group 2, we used a sample calculated from the formula proposed by Luiz and Magnanini ${ }^{(17)}$, considering the prevalences described in a previous study carried out with women in primary care $(25.8 \%$ of the women were users of psychotropic drugs, and $74.2 \%$ were not $)^{(18)}$.

We adopted the 95\% confidence level and a tolerable sampling error of $10 \%$. The sample size obtained in the calculation was of 70 women, whose medical charts were drawn from a list provided by the unit.

\section{Data COllection}

The data collection period was from July 2015 to March 2016, and the sources of the clinical and sociodemographic data were the charts, respective registration forms, and the prescription records of the pharmacy of the referred health unit.

The data collected from the charts were the birth dates, the $\mathrm{BZD}$ prescribed, the dosage of the latest prescription, and whether or not there was a concomitant use of other psychotropics. Regarding the registration forms, we collected the following data: age, education level, occupation, number of family members, income, whether or not the family received some government aid other than pension or retirement, and the existence of some chronic illness.

\section{Data ANALYSIS AND TREATMENT}

We inserted the data into a database created in the software Statistical Package for the Social Sciences (IBM SPSS Statistics 20). We performed descriptive analyses, association tests (Pearson's chi-squared or Fisher's exact), test of difference of means or medians (Student's t or Mann-Whitney), and logistic regression analysis.

We accepted the hypothesis of association or difference when the $\mathrm{p}$-value was lower than 0.05 . In the comparative analyses between groups, we excluded women whose missing data corresponded to over $30 \%$ of all collected data. Thus, we excluded from the data analysis 17 women who were BZD users. Into the logistic regression model, we inserted only variables that presented significance in the association test. We verified the model's adequacy using the HosmerLemeshow goodness of fit test. 


\section{ETHICAL ASPECTS}

The project was submitted to the appreciation of the Research Ethics Committee of the School of Nursing of Ribeirão Preto of the Universidade de São Paulo and approved under protocol no. 1.151.714 on June 5th, 2015. We observed the ethical aspects of research involving human beings, following Resolution no. 466/2012 of the Brazilian National Health Council.

\section{RESULTS}

We identified 81 BZD users among the 1,094 adult women cared for at the $\mathrm{FHU}$, which corresponds to a $7.4 \%$ prevalence of BZD usage. Table 1 shows a comparative chart of the profile of BZD user and non-user women regarding the variables studied.

The age range of most BZD users was of 56 to 74 years (48.4\%), while the non-users $(45.7 \%)$ were in the 37 to 55 -year range. Thus, one may surmise that the mean age of women who used BZD was significantly higher than that of the non-users $(p=0.005)$ (Table 1$)$.

The BZD users were also less alphabetized: $65.6 \%$ had at most an elementary education level, while in the other group 58.6\% had education levels higher than the elementary ( $p=0.005)$. Furthermore, $78.1 \%$ of the users reported having some chronic illness, and there was a difference between the two groups in this regard $(p<0.001)$ (Table 1).

Almost half of the BZD users consumed at least one other psychotropic drug (48.4\%), presenting a significant difference compared to the non-users of BZD $(17.1 \%$ and $\mathrm{p}<0.001)$ (Table 1).

The BZD users also consumed a higher number of other psychotropic drugs (the position average of users was of 78.18, compared to 57.74 of non-users; $p<0.001$ ). The most used psychotropics besides the BZD were the antidepressants.

Given that we identified the consumption of psychotropics in both groups $(n=43)$, we verified that the majority ( $n$ $=35$ ) used only one psychotropic other than BZD. Among the BZD users, the most consumed psychotropics other than BZD and antidepressants were antipsychotics (9.5\%). For the non-users of BZD, other than antidepressants, anticonvulsants were the most used (10\%). Only BZD users consumed humor stabilizers (4.8\%).

Regarding the self-reported illnesses, $60.4 \%$ of all participants mentioned having some chronic disease (Figure 1), and the most reported illnesses in both groups were hypertension and diabetes.

Table 1 - Comparison of the sociodemographic characteristics between users and non-users of benzodiazepines - São Carlos, SP, Brazil, 2015-2016.

\begin{tabular}{|c|c|c|c|c|c|c|}
\hline \multirow{3}{*}{ Sociodemographic characteristics } & & \multicolumn{4}{|c|}{ Benzodiazepine User } & \multirow{3}{*}{$p$ value } \\
\hline & & \multicolumn{2}{|c|}{ No $(\mathbf{n}=70)$} & \multicolumn{2}{|c|}{ Yes $(n=64)$} & \\
\hline & & $\mathbf{n}$ & $\%$ & $\mathbf{n}$ & $\%$ & \\
\hline \multirow[t]{7}{*}{ Age } & From 18 to 36 Years & 19 & 27.1 & 7 & 10.9 & \multirow{7}{*}{$0.005^{+}$} \\
\hline & From 37 to 55 years & 32 & 45.7 & 23 & 35.9 & \\
\hline & From 56 to 74 years & 15 & 21.4 & 31 & 48.4 & \\
\hline & From 74 to 92 years & 4 & 5.7 & 3 & 5.7 & \\
\hline & Mean (standard deviation) & & & & & \\
\hline & Non-users 48.1 (16.4) & & & & & \\
\hline & Users 55.3 (12.9) & & & & & \\
\hline \multirow[t]{2}{*}{ Education level } & Up to complete elementary level & 29 & 41.4 & 42 & 65.6 & \multirow[b]{2}{*}{$0.005^{\ddagger}$} \\
\hline & $\begin{array}{l}\text { Over the complete elementary } \\
\text { level }\end{array}$ & 41 & 58.6 & 22 & 34.4 & \\
\hline \multirow[t]{2}{*}{ Occupation } & Does not work outside the home & 33 & 47.1 & 34 & 53.1 & \multirow{2}{*}{$0.489^{\ddagger}$} \\
\hline & Works outside the home & 37 & 52.9 & 30 & 46.9 & \\
\hline \multirow[t]{2}{*}{ Number of Family members } & Up the three people & 33 & 47.1 & 36 & 56.3 & \multirow{2}{*}{$0.292^{\ddagger}$} \\
\hline & Over three people & 37 & 52.9 & 28 & 43.8 & \\
\hline \multirow[t]{2}{*}{ Income $^{+}$} & Up to two minimum wages* & 20 & 28.6 & 19 & 29.7 & \multirow{2}{*}{$0.629^{\ddagger}$} \\
\hline & Over two minimum wages* & 26 & 37.1 & 20 & 31.3 & \\
\hline \multirow[t]{2}{*}{ Home owner ${ }^{\S}$} & Yes & 58 & 82.9 & 55 & 85.9 & \multirow{2}{*}{$0.118^{\ddagger}$} \\
\hline & No & 9 & 12.9 & 3 & 4.7 & \\
\hline \multirow[t]{2}{*}{ Reports some chronic disease } & Yes & 28 & 40.0 & 53 & 82.8 & \multirow{2}{*}{$<0.001^{\ddagger}$} \\
\hline & No & 42 & 60.0 & 11 & 17.2 & \\
\hline \multirow[t]{2}{*}{ Uses another psychotropic drug } & Yes & 12 & 17.1 & 31 & 48.4 & \multirow{2}{*}{$<0.001^{\ddagger}$} \\
\hline & No & 58 & 82.9 & 33 & 51.6 & \\
\hline \multirow[t]{2}{*}{ Bolsa famílial| } & Yes & 3 & 4.3 & 3 & 4.7 & \multirow{2}{*}{$0.852^{\ddagger}$} \\
\hline & No & 48 & 68.6 & 41 & 64.1 & \\
\hline
\end{tabular}

*Monthly minimum wage at the time of data collection: $\mathrm{R} \$ 880.00$; †Student's t-test; $\neq$ Chi-squared or Fisher’s exact test; $† 49$ participants did not report their income; $\$ 9$ participants did not report if they were homeowners; ||39 participants did not report whether or not they were Bolsa Familia (Brazilian social welfare program) recipients. Note: $(n=134)$. 
Among the BZD users, we observed that $46.9 \%(n=30)$ were hypertensive and $17.2 \%(\mathrm{n}=11)$ were diabetic, whereas in the non-user group, $22.9 \%(\mathrm{n}=16)$ were hypertensive and $10 \%(n=7)$ were diabetic. The difference between the number of women that reported having hypertension in both groups was significant $(\mathrm{p}=0.003)$.

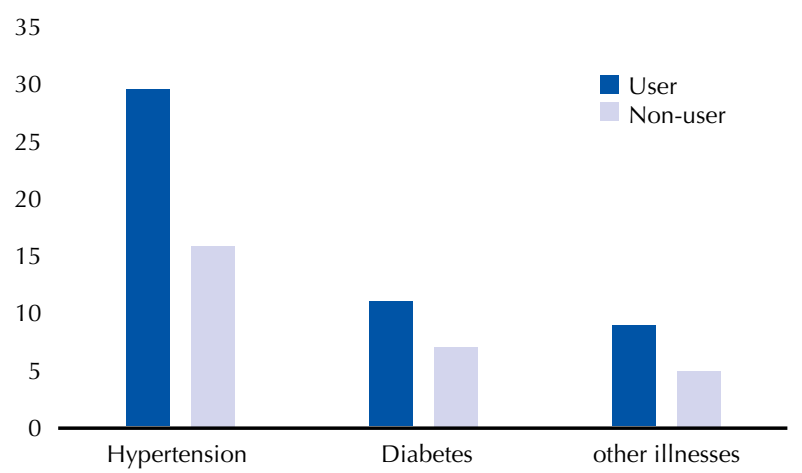

Figure 1 - Frequency of women who reported having some chronic illness among the users and non-users of benzodiazepines - São Carlos, SP, Brazil, 2015-2016.

Note: $(n=134)$.

Regarding the number of reported illnesses, the women who were BZD users presented more diseases than the nonusers (position averages: 82.1 and 54.2, respectively; $\mathrm{p}<0.001$ ).

We used the variables representing the use of other psychotropics, education level, age, and self-reported illnesses, whose association tests presented significant results in the comparison between the two groups, to create an explicative model about the factors associated with BZD usage. Table 2 presents the model that best explained this use.

Consuming another psychotropic drug and having selfreported illnesses constituted risk factors for BZD usage in the sample studied. The women who used other psychotropics presented 5.17 times more chances of using BZD than those who did not, whereas women who reported having some chronic illness were 4.8 times more likely to use BZD than those who did not.

Table 2 - Factors associated with the use of benzodiazepines according to the final logistic regression model - São Carlos, SP, Brazil, 2015-2016.

\begin{tabular}{lllll}
\hline \multirow{2}{*}{ Factors } & \multirow{2}{*}{$\mathrm{p}$ value } & \multirow{2}{*}{$\begin{array}{l}\text { Odds } \\
\text { ratio }\end{array}$} & \multicolumn{2}{l}{ Confidence interval (95\%) } \\
\cline { 4 - 5 } & & & Lower limit & Upper limit \\
\hline Use of other psychotropic & 0.000 & 5.176 & 2.134 & 12.553 \\
Reported illnesses & 0.001 & 4.797 & 1.832 & 12.563 \\
Education Level & 0.180 & 1.828 & 0.757 & 4.415 \\
Age & 0.837 & 0.997 & 0.965 & 1.029 \\
\hline
\end{tabular}

\section{DISCUSSION}

Regarding the age mean of the BZD users identified in this study (55 years), a previous research effort ${ }^{(6)}$ presented the same mean. In another study ${ }^{(5)}$, the authors reported an average of 57 years and stated that the proportion of female users increased with age, thus corroborating this study's findings.
However, the prescription of such medicines for older patients is seen as inadequate by some authors because they increase the risk of falling and, consequently, of fractures, especially the BZDs with long half-lives. It is recommended that, when the use of such drugs is indispensable, low dosages should be prescribed and short half-life BZDs, because this population presents physiological modifications that interfere with the metabolization of the medicines, making them more vulnerable to drug interactions and adverse reactions ${ }^{(19)}$.

The positive correlation between advanced age and BZD usage is well described in the literature, so much so that several authors dedicate their studies exclusively to this population. Since aging may often be accompanied by the emergence of sleep disorders, anxiety, depression, and neurodegenerative illnesses, it is considered that such conditions may contribute to the increase in psychotropic consumption in this phase of life ${ }^{(7)}$

The women in both groups of this study's sample had low education levels, but this index was higher among the BZD users. The education level has been described as an important factor related to the onset of health problems both for the women themselves as for the children under their care. Besides, in a previous study carried out in primary care, it was observed that people with low education levels are 1.7 times more likely to use psychotropics ${ }^{(18)}$.

There was a significant difference between BZD users and non-users regarding the education level. Women who used BZD were those who least studied (65.6\%). However, this risk factor did not show to be significant in the final regression model. It is our understanding that such a condition may reduce access to information about the damages related to chronic BZD usage.

Furthermore, a low education level is directly linked to the higher difficulty of having good professional and socialascension chances, "possibly contributing to a worse quality of life, odds of developing Common Mental Disorders and, consequently, an increase in the probability of using psychotropics"(18).

Regarding the profile of the families to which the women in the study belonged, we identified they were, in general, constituted by three to four people, with own housing and non-beneficiaries of governmental social programs. Concerning family income, we observed a predominance of women who reported earning over two minimum wages in both groups, but the interpretation of this result is limited due to the large percentage of missing data regarding this variable.

Nevertheless, considering the characteristics of the territory in which the FHU is located, it is suggested that this study's population was composed of women who did not appear to present significant social vulnerabilities despite the low education levels and the non-exercise of paid work by most of them.

We identified that $7.4 \%$ of the adult women registered in the referred health unit were BZD users. Prevalence is a data difficult to analyze, seeing that among the studies there are population peculiarities as well as differences regarding the location studied, sampling strategies, and data sources 
employed - factors that may determine the prevalence variations. Furthermore, we understand that the sociodemographic characteristics specific to each study's population may also contribute to the variability.

Thus, the prevalence described in previous studies $^{(5,6,16,18-20)}$ varies between $2.5 \%$ and $16.8 \%$. Among the studies carried out in primary care, one of them ${ }^{(19)}$ reports the prevalence of $2.5 \%$ of women who were BZD users; however, for data collection, the authors used only people who were BZD users in the previous six months from data obtained by the city's information system.

Another study ${ }^{(18)}$ performed at a PHU presented, from primary data, a prevalence of $13 \%$. Hence, the prevalence found in this study (7.4\%) was below that described in previous research. This result answers one of this study's questions, suggesting that the FHUs have a more preventive focus and that the actions of their teams stem from a broader health perspective. We believe such characteristics may have contributed to this finding.

An additional relevant result of this study was the identification that women with self-reported illnesses were 4.8 times more likely to use BZD than those who did not report diseases. A recent research effort pointed out that patients who are BZD users present higher medical comorbidity levels. This finding was verified from the identification that an increase in the frequency of medical diagnostics and higher rates of use of health services associated with the prescription of this type of medicine exist ${ }^{(6)}$

The authors of the cited study proposed two explanations for their results: patients with a more significant number of clinical comorbidities are more likely to be prescribed BZD; and/or that the BZDs may increase the risk of adverse results for the health of users. Another finding of this same study is related to the excessive number of medical BZD prescriptions to patients who presented factors that contraindicated their consumption such as advanced age, pulmonary diseases, osteoporosis, and disorders related to substance use. This would reflect in the worsening of the quality of life presented by such patients ${ }^{(6)}$.

As described in Table 1, BZD users reported significantly more chronic illnesses than non-users $(p<0.001)$. The regression model built points out that the women who reported some disease were almost five times more likely to use some type of BZD.

The two illnesses which stood out in this study in both groups were the chronic diseases more commonly observed in the general population: arterial hypertension and diabetes. What was notable, however, was the observation that in the group of BZD users, the percentage of women who reported arterial hypertension was more than the double.

"The prevalence of self-reported systemic arterial hypertension in Brazil is of $20.9 \%$ "(21) . In this study, $22.9 \%$ of the non-users of BZD were hypertensive and, among the BZD users, $46.9 \%$ - over the double of the general population, yet close to the prevalence found by a study carried out specifically with hypertensive BZD users ${ }^{(22)}$.

The relationship between anxiety and arterial hypertension is an old theme in the academic environment; nevertheless, it is not as clear as it may seem. A literature review $^{(23)}$ pointed out that many non-elucidated questions remain and that one illness in fact influences the other. Still, it described that such influence might be in varied forms depending, inclusively, on the individual's type of psychological answer.

For example, the use of defense mechanisms such as affective dullness in the face of anxiogenic situations or in anxious patients may cause a drop in arterial pressure. Another relevant data is that the diagnosis of hypertension itself may cause anxiety. However, some authors state that prescribing anxiolytics to all hypertensive patients is not a good therapeutic path because hypertension is not always caused by anxiety or will, necessarily, generate pathological anxiety in patients ${ }^{(6,23)}$.

The sample studied presented a higher percentage of diabetics (10\% among non-users and $17.2 \%$ among users of BZD) when compared with a recent study, which indicated a prevalence of $6.2 \%$ of people who reported being diabetics in $\mathrm{Brazil}^{(24)}$.

Regarding the association between having diabetes and using BZD, despite the percentage of women with diabetes being higher among the users, the association test did not demonstrate being a significant result $(p=0.223)$. Another Brazilian study also performed in primary care presented higher results ${ }^{(25)}$.

Researchers from Taiwan described a higher prevalence of diabetes in patients with anxiety disorders (11.89\%) when compared to the general population $(5.92 \%)^{(26)}$. The authors suggest two explanations for this finding: the first would be that physiological modifications caused by anxiety may generate an unbalance in the regulation of the hypothalamus-pituitary-adrenal pathway, resulting in high cortisol levels which may inhibit the function of insulin in several ways. The other explanation would be that the patients with anxiety disorders generally use psychotropic drugs such as antipsychotics, antidepressants, humor stabilizers, and benzodiazepines, which would contribute to weight gain and the development of hyperglycemia, hypertension, and hyperlipidemia ${ }^{(26)}$.

An Australian longitudinal study about anxiety and diabetes observed that the probability of developing diabetes was higher among women who had persistent symptoms of anxiety. The two physiological explanations of the authors cited before were also described by the Australian researchers ${ }^{(27)}$. Even so, due to the many confounding variables that could not be controlled, the results were not conclusive to the point of stating that anxiety leads to the development of diabetes. However, what may be concluded is that only persistent symptoms of anxiety can be associated with a modest increase in the risk of developing diabetes ${ }^{(27)}$.

Nearly half the women in this study (48.4\%) reported using BZD concomitantly with other psychotropic medicines. We also identified that using other psychotropics was a risk factor, that is, women who consumed other psychotropics were 5.17 times more likely to use BZD than those who did not. The most present combination was that of 
antidepressants and BZD, which is in agreement with previous studies ${ }^{(10)}$.

The fact that nearly half the BZD users also consumed other psychotropic drugs may raise two suspicions, namely: given that diagnostics of mental disorders are generally neither unique nor static, a condition of anxiety, for example, may evolve to depression and vice-versa, so the association of psychotropics is a common practice in psychiatry and the BZD users probably already consumed other psychotropics or started using them simultaneously; the other possibility is that the continuous use of BZD itself, often prescribed for problems such as insomnia, may generate a depressive condition or another psychic problem due to the neurochemical transformations that the substance may cause.

There is also the potential risk of combining drugs that directly act on the Central Nervous System (CNS). Although combinations are often used for treating mental illnesses, drug interactions with mild to severe effects may occur.

Another relevant issue is to understand that people in emotional suffering often somatize, making a problem of psychic origin physical, which leads to the consumption of more medicines. In this sense, in addition to this combination, some authors emphasize that individuals with common mental disorders are more susceptible to the prescription of a larger number of psychotropics and other drugs, leading to even more significant risks ${ }^{(16,18)}$.

Therefore, the awareness about the risks (both by users and by physicians and other members of the health team) and the materialization of the institutional support by the mental health specialists are essential so that the prescription of BZD and other psychotropic drugs does not constitute as a first or only therapeutic alternative for anxiety disorders and other mental sufferings, especially by primary care physicians.

This data gives rise to a critical reflection that may be expanded under two viewpoints. Firstly, it is questionable whether such prescriptions correspond to the current clinical condition of the users, i.e., if the diagnosis and therapeutics are appropriate. If the answer to this question is affirmative, we surmise, secondly, that the teams working in the referred FHU are being somewhat contingent with the mental health demands of the community, since, formerly, such women would be hospitalized or accompanied merely by the specialized services.

From these questionings, we recommend that the teams also pay attention to the psychosocial needs of people with mental disorders, discussing and undertaking efforts to implement social insertion and reinsertion actions as well as the broadening of the support networks that may be strategic to aiding the contention of the symptoms and the improvement of the quality of life of these people, thus avoiding the need for using more psychotropics and/or services of higher complexity.

The principal limitations of this study were the use of secondary data, mainly due to the lack of some information and the precariousness of the organization of the unit's records, as well as the collection of data in only one health unit. It is our understanding that widening the sample by including more health services could generate even more significant results. For future research, we suggest the development of a study with primary data and also using qualitative techniques so to deepen the analysis of the phenomenon considering the perception of the users themselves.

\section{CONCLUSION}

The prevalence of BZD use among the women studied was smaller than the identified in previous studies in PHUs. Regarding the risk factors, having a chronic illness and using another psychotropic drug were significantly associated with the use of BZD, a result stemming both from the bivariate analyses and from logistic regression. There was a significant association of the education level with BZD use only in the bivariate analyses. Income did not constitute as an associated factor in any of the tests performed.

This study presents significant contributions to the health area. Firstly, one must observe the issues related to the identification of risk factors because, in the current context marked by strong gender discrimination, being a woman by itself characterizes a vulnerability situation. Hence, the characteristics we identified in this sample such as low education level, high average age, and having a chronic illness emphasize a set of risk factors to which women are exposed. We also highlight that, as shown in the results, many women probably have the diagnostic of some mental disorder, given the use of several psychotropic drugs, including antipsychotics.

Secondly, it is worth stressing the issues related to the conscious prescription of $\mathrm{BZD}$, because an aspect that deserves emphasis refers to the risks of drug association in using substances that directly act on the CNS. As pointed out in this study, such an association may be even more aggravated in this population due to the high rate of self-referred chronic illnesses, especially diabetes and hypertension, seeing that, besides the psychotropics, there is also the consumption of medicines to control such diseases.

It is also necessary to underscore the identification of more vulnerable groups regarding BZD use, i.e., when also considering the potential health risks that the chronic use of BZD might cause, we conclude that the group that should receive more attention regarding the consumption of this substance is that of middle-aged women or older, with low education levels, and chronic illnesses.

In short, it is our understanding that the FHU teams need the support of mental health teams to widen their offer of community interventions and mental health promotion actions of psychosocial nature which are alternative and/or complementary to the purely medical treatment.

In view of this set of considerations, it is worth highlighting that nurses have a crucial role in the work process of family health teams, and their diversified range of knowledge and functions is of utmost importance so that the recommendations proposed in this study are considered when planning the users' care, especially in the area of primary care. 


\section{RESUMO}

Objetivo: Estimar a prevalência do uso de benzodiazepínicos por mulheres adultas em uma Unidade de Saúde da Família e identificar os fatores de risco associados a esse uso. Método: Estudo quantitativo de corte transversal, que se utilizou de dados secundários, desenvolvidos em uma Unidade de Saúde da Família do interior de São Paulo. Os dados foram coletados entre a partir das seguintes fontes: prontuários, fichas cadastrais e arquivo de receitas da farmácia da referida unidade de saúde. Foram utilizados os testes qui-quadrado, t de Student, Mann-Whitney e análise de regressão logística. Resultados: Foram identificadas 81 usuárias de benzodiazepínicos entre 1.094 mulheres adultas (7,4\%). Em relação aos fatores de risco, a comparação dos grupos de usuárias $(\mathrm{n}=64)$ e não usuárias de benzodiazepínicos $(\mathrm{n}=70)$ apontou que ter doença crônica e usar outro psicotrópico foram significativamente associados ao uso de benzodiazepínicos. Conclusão: A prevalência encontrada foi menor do que a descrita em estudos prévios realizados em Unidades Básicas de Saúde. O grupo que deve receber maior atenção em relação ao consumo de benzodiazepínicos é o de mulheres de meia-idade ou mais, com pouca escolaridade e doença crônica.

\section{DESCRITORES}

Psicotrópicos; Mulheres; Prevalência; Fatores de Risco; Doença Crônica; Estratégia Saúde da Família.

\section{RESUMEN}

Objetivo: Estimar la prevalencia del empleo de benzodiazepinas por mujeres adultas en una Unidad de Salud de la Familia e identificar los factores de riesgo asociados con dicho uso. Método: Estudio cuantitativo de cohorte transversal, que se utilizó de datos secundarios, desarrollados en una Unidad de Salud de la Familia del interior de São Paulo. Los datos fueron recogidos de las siguientes fuentes: fichas médicas, fichas de registro y archivo de recetas de la farmacia de la mencionada unidad de salud. Fueron utilizadas las pruebas de Chi cuadrado, t de Student, Mann-Whitney y análisis de regresión logística. Resultados: Fueron identificadas 81 usuarias de benzodiazepinas entre 1.094 mujeres adultas $(7,4 \%)$. Con respecto a los factores de riesgo, la comparación de los grupos de usuarias $(\mathrm{n}=$ 64) y no usuarias de benzodiazepinas $(n=70)$ señaló que tener enfermedad crónica y usar otro psicótropo estuvieron significativamente asociados con el uso de benzodiazepinas. Conclusión: La prevalencia encontrada fue menor que la descrita en estudios previos realizados en Unidades Básicas de Salud. El grupo que debe recibir mayor atención con relación al consumo de benzodiazepinas es el de mujeres de mediana edad o más, con poca escolaridad y enfermedad crónica.

\section{DESCRIPTORES}

Psicotrópicos; Mujeres; Prevalencia; Factores de Riesgo; Enfermedad Crónica; Estrategia de Salud Familiar.

\section{REFERENCES}

1. Azevedo AJP, Araújo AA, Ferreira MAF. Consumo de ansiolíticos benzodiazepínicos: uma correlação entre dados do SNGPC e indicadores sociodemográficos nas capitais brasileiras. Ciênc Saúde Coletiva [Internet]. 2016 [citado 2016 dez. 30];21(1):83-90. Disponível em: http:// www.scielo.br/pdf/csc/v21n1/1413-8123-csc-21-01-0083.pdf

2. International Narcotics Control Board. Psychotropic substances: statistics for 2013 [Internet]. New York: United Nations; 2014 [cited 2016 Dec 30]. Available from: https://www.incb.org/documents/Psychotropics/technical-publications/2013/en/English_2013_Tech_pub.pdf

3. International Narcotics Control Board. Psychotropic substances: statistics for 2014. [Internet]. New York: United Nations; 2015 [cited 2016 Dec 30]. Available from: https://www.unodc.org/documents/southeastasiaandpacific/Publications/2015/incb/INCB_Annual_Report_2014_ EN.pdf

4. World Health Organization. Programme on substance abuse: rational use of benzodiazepine [Internet]. Geneva: WHO; 1996 [cited 2016 Dec 30]. Available from: https://www.erowid.org/pharms/benzodiazepine/benzodiazepine_info1.pdf

5. Bénard-Laribière $A$, Noize $P$, Pambrun $E$, Bazin F, Verdoux $H$, Tournier $M$, et al. Comorbidities and concurrent medications increasing the risk of adverse drug reactions: prevalence in French benzodiazepine users. Eur J Clin Pharmacol. 2016;72(7):869-76. DOI: https://doi. org/10.1007/s00228-016-2044-y

6. Kroll DS, Nieva HR, Barsky AJ, Linder JA. Benzodiazepines are prescribed more frequently to patients already at risk for benzodiazepinerelated adverse events in primary care. J Gen Intern Med [Internet]. 2016[cited 2016 Dec 30];31(9):1027-34. Available from: https://www. ncbi.nlm.nih.gov/pmc/articles/PMC4978684/

7. Morgan SG, Weymann D, Pratt B, Smolina K, Gladstone EJ, Raymond C, et al. Sex differences in the risk of receiving potentially inappropriate prescriptions among older adults. Age Ageing [Internet]. 2016 [cited 2016 Dec 30];45(4):535-42. Available from: https:// www.ncbi.nlm.nih.gov/pmc/articles/PMC4916346/

8. Alonso F, Esteban C, Montoro L, Tortosa F. Psychotropic drugs and driving: prevalence and types. Ann Gen Psychiatry [Internet]. 2014[cited 2016 Dec 30];13:14. Available from: https://www.ncbi.nlm.nih.gov/pmc/articles/PMC4018967/

9. Riska BS, Skurtveit S, Furu K, Engeland A, Handal M. Dispensing of benzodiazepines and benzodiazepine-related drugs to pregnant women: a population-based cohort study. Eur J Clin Pharmacol. 2014;70(11):1367-74.

10. Souza ARL, Opaleye ES, Noto AR. Contextos e padrões do uso indevido de benzodiazepínicos entre mulheres. Ciênc Saúde Coletiva [Internet]. 2013 [citado 2016 dez. 30];18(4):1131-40. Disponível em: http://www.scielo.br/scielo.php?script=sci_arttext\&pid $=$ S1413-81232013000400026

11. Canham SL. What's loneliness got to do with it? Older women who use benzodiazepines. Australas J Ageing. 2015;34(1):E7-E12.

12. Smith M, Frey BN. Treating comorbid premenstrual dysphoric disorder in women with bipolar disorder. J Psychiatry Neurosci [Internet]. 2016 [cited 2016 Dec 30];41(2):E22-E23. Available from: https://www.ncbi.nlm.nih.gov/pmc/articles/PMC4764487/

13. Petersen I, McCrea RL, Sammon CJ, Osborn DP, Evans SJ, Cowen PJ, et al. Risks and benefits of psychotropic medication in pregnancy: cohort studies based on UK electronic primary care health records. Health Technol Assess [Internet]. 2016 [cited 2016 Dec 30];20(23):1 176. Available from: https://www.ncbi.nlm.nih.gov/books/NBK350789/ 
14. Vicens C, Bejarano F, Sempere E, Mateu C, Fiol F, Socias I, et al. Comparative efficacy of two interventions to discontinue long-term benzodiazepine use: cluster randomised controlled trial in primary care. Br J Psychiatry. 2014;204(6):471-9.

15. Borges TL, Hegadoren KM, Miasso AI. Transtornos mentais comuns e uso de psicofármacos em mulheres atendidas em unidades básicas de saúde em um centro urbano brasileiro. Rev Panam Salud Pública [Internet]. 2015 [citado 2016 dez. 8];38(3):195-201. Disponível em: http://www.scielosp.org/pdf/rpsp/v38n3/v38n3a03.pdf

16. Rocha BS, Werlang MC. Psicofármacos na Estratégia Saúde da Família: perfil de utilização, acesso e estratégias para a promoção do uso racional. Ciênc Saúde Coletiva [Internet]. 2013 [citado 2016 dez. 30];18(11):3291-300. Disponível em: http://www.scielo.br/scielo. php?script=sci_arttext\&pid=S1413-81232013001100019

17. Luiz RR, Magnanini MMF. A lógica da determinação do tamanho da amostra em investigações epidemiológicas. Cad Saúde Coletiva. 2000;8(2):9-28.

18. Borges TL, Miasso AI, Vedana KGG, Telles Filho PCP, Hegadoren KM. Prevalência do uso de psicotrópicos e fatores associados na atenção primária à saúde. Acta Paul Enferm [Internet]. 2015 [citado 2016 dez. 15];28(4):344-9. Disponível em: http://www.scielo.br/pdf/ape/ v28n4/1982-0194-ape-28-04-0344.pdf

19. Queiroz Netto MU, Freitas O, Pereira LRL. Antidepressivos e benzodiazepínicos: estudo sobre o uso racional entre usuários do SUS em Ribeirão Preto-SP. Rev Ciênc Farm Básica Apl. 2012;33(1):77-81

20. Quintana MI, Andreoli SB, Peluffo MP, Ribeiro WS, Feijo MM, Bressan RA, et al. Psychotropic drug use in São Paulo, Brazil: an epidemiological survey. PLoS One [Internet]. 2015[cited 2016 Dec 30];10(8):e0135059. Available from: https://www.ncbi.nlm.nih.gov/ pmc/articles/PMC4529275/

21. Moreira JPL, Moraes JR, Luiz RR. Prevalence of self-reported systemic arterial hypertension in urban and rural environments in Brazil: a population-based study. Cad Saúde Pública [Internet]. 2013 [cited 2016 Dec 30];29(1):62-72. Available from: http://www.scielo.br/scielo. php?script=sci_arttext\&pid=S0102-311X2013000100008\&lng=en\&nrm=iso\&tlng=en

22. Tomas A, Horvat O, Tomic Z, Ban M, Sabo A. Pattern of benzodiazepines utilization in outpatients with hypertension in Serbia. Value Health. 2014;17(7):A504.

23. Byrd JB, Brook RD. Anxiety in the "age of hypertension". Curr Hypertens Rep. 2014;16(10):486.

24. Iser BPM, Stopa SR, Chueiri PS, Szwarcwald CL, Malta DC, Monteiro HOC, et al. Prevalência de diabetes autorreferido no Brasil: resultados da Pesquisa Nacional de Saúde 2013. Epidemiol Serv Saúde [Internet]. 2015 [citado 2016 dez. 30];24(2):305-14. Disponível em: http:// www.scielo.br/scielo.php?script=sci_arttext\&pid=S2237-96222015000200305

25. Silva VP, Botti NCL, Oliveira VC, Guimarães EAA. Perfil epidemiológico dos usuários de benzodiazepínicos na atenção primária à saúde. Rev Enferm Cent Oeste Min [Internet]. 2015 [citado 2016 dez. 30];5(1):1393-400. Disponível em: http://www.seer.ufsj.edu.br/index.php/ recom/article/view/546

26. Chien IC, Lin CH. Increased risk of diabetes in patients with anxiety disorders: a population-based study. J Psychosom Res. 2016;86:47-52.

27. Hasan SS, Clavarino AM, Mamun AA, Kairuz T. Anxiety symptoms and the risk of diabetes mellitus in Australian women: evidence from 21-year follow-up. Public Health. 2016;130:21-8. 